Piotr Goniszewski

University of Szczecin

piotr.goniszewski@interia.pl

ORCID: 0000-0002-1090-9846

DOI: http://dx.doi.org/10.12775/BPTh.2018.014

\section{Biblica}

et

Patristica

Thoruniensia

11 (2018) 3: 301-313

ISSN (print) 1689-5150

ISSN (online) 2450-7059

\title{
The Men Redeemed or Unredeemed? Interpretations of Rom 7:14-25 in Aquinas's Super \\ Epistolam B. Pauli ad Romanos lectura and in Contemporary Exegesis
}

\section{Ludzie odkupieni czy nieodkupieni? Interpretacje Rz 7,14-25 w Komentarzu do Listu do Rzymian Tomasza z Akwinu oraz we współczesnych komentarzach biblijnych}

\begin{abstract}
This article focuses on the pericope of Rom 7:14-25, especially on the problem of understanding the rhetorical 'I' in Aquinas's Ad Rom, as well as in selected twentieth-century biblical commentaries.

The first part of the article offers the analysis of Aquinas's reflections on Rom 7:14-25, where we find an exegetical explanation of the pronoun 'I' in Ad Rom. The second part includes the opinions of contemporary biblical scholars on the rhetorical 'I' of the pericope. The first scholar is Karl Barth whose well-known monograph Römerbrief is an example of the philosophical (or anti-philosophical) and theological approaches to St Paul's epistle. The second scholar is Douglas J. Moo, who represents classical historical-critical exegesis of Romans.
\end{abstract}

Streszczenie. Celem tego artykułu jest analiza perykopy Rz 7,14-25, a szczególnie problem rozumienia retorycznego ,ja” w Komentarzu do Listu do Rzymian Tomasza z Akwinu oraz w przykładowych, XX-wiecznych komentarzach biblijnych.

W pierwszej części artykułu koncentrujemy się na tekście Akwinaty i jego interpretacji Rz 7,14-25. Rozważania egzegetyczne obracają się wokół właściwego odczytania funkcji zaimka osobowego „ja” w ujęciu Tomasza. Druga część poświęcona jest dwóm, wybranym i współczesnym komentatorom do Rz 7,14-25. Pierwszym z nich jest przedstawiciel filozoficznego albo nawet anty-filozoficznego podejścia do Listu do Rzymian, czyli Karl Barth, autor jednego z najważniejszych dzieł XX-wiecznej teologii 
Römerbrief. Z kolei drugim jest Douglas J. Moo, przedstawiciel typowego dla współczesnej egzegezy stylu komentowania Listu do Rzymian, bazującego na metodzie historyczno-krytycznej.

Keywords: Thomas Aquinas; Karl Barth; Douglas J. Moo; Rom 7:14-25; exegesis.

Słowa klucze: Tomasz z Akwinu; Karl Barth; Douglas J. Moo; Rz 7,14-25; egzegeza.

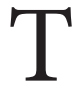
he Super Epistolam B. Pauli ad Romanos lectura (hereafter ad Rom) of Thomas Aquinas is one of the most famous biblical commentaries written in the Middle Ages. This text is part of a larger collection of readings and commentaries on all of the letters of the Apostle to the Nations (the so-called Corpus Paulinum). According to J.-P. Torrell, Aquinas probably wrote this book at the conclusion of his scientific work in Naples, between 1272-73. ${ }^{1}$ Thomas Prügl, however, suggests that the commentaries on Paul's epistles were the primary subject of the lectures of the new magister in sacra pagina in $1256 .{ }^{2}$ The commentary, along with a reading on the Gospel of St. John (Lectura super Ioannem), is an example of a perfect synthesis of philosophy, theology, and biblical exegesis. Thomas Aquinas's remarks are still valid and may constitute a valuable contribution to contemporary research on the Bible. The present stalemate of diachronically historical-critical methods once again creates an opportunity for alternative methods of interpreting the Scriptures. Biblical Thomism may bring revealing insights to this hermeneutic process. ${ }^{3}$

In this paper, I would like to focus on the pericope Rom 7:14-25, especially on the problem of understanding the rhetorical ' $\mathrm{I}$ ' in Aquinas's Ad Rom, as

1 For more on this topic, see J.-P. Torrell, Tomasz $z$ Akwinu, pp. 294-302.

2 T. Prügl, Thomas Aquinas as Interpreter, pp. 386-415. See also: R. Wielockx, Au sujet du commentaire de Saint Thomas, pp. 150-177.

3 The most famous representative of Biblical Thomism is undoubtedly Matthew Levering; among his works, the following are particularly worthy of attention: M. Levering, Pismo Święte i metafizyka; see also: M. Dauphinais, M. Levering (eds.), Reading John with St. Thomas Aquinas; M. Levering, M. Dauphinais (eds.), Reading Romans with St. Thomas Aquinas. In Poland, Torun is an important research centre for Biblical Thomism. Scholars associated with the Faculty of Theology of Nicolaus Copernicus University in Torun have begun editing the commentaries of Thomas Aquinas on the letters of St. Paul: Tomasz z Akwinu, Wykład listu do Kolosan; idem, Wykład pierwszego listu do Tymoteusza. Other researchers from other parts of Poland are involved in this work. About contemporary research on various aspects of Biblical Thomism see also: P. Roszak, J. Vijgen (eds.), Towards a Biblical Thomism.; idem, Reading Sacred Scripture. 
well as on the twentieth-century biblical commentators. In the first part of the article, I will analyze Aquinas's reflections on Rom 7:14-25, ${ }^{4}$ where we find an

4 The Latin text of Rom 7:14-25 (Jerome's Vulgate) reads as follows: $7,{ }^{14}$ Scimus enim quod lex spiritalis est ego autem carnalis sum venundatus sub peccato ${ }^{15}$ quod enim operor non intellego non enim quod volo hoc ago sed quod odi illud facio ${ }^{16}$ si autem quod nolo illud facio consentio legi quoniam bona ${ }^{17}$ nunc autem iam non ego operor illud sed quod habitat in me peccatum ${ }^{18}$ scio enim quia non habitat in me hoc est in carne mea bonum nam velle adiacet mihi perficere autem bonum non invenio ${ }^{19}$ non enim quod volo bonum hoc facio sed quod nolo malum hoc ago ${ }^{20}$ si autem quod nolo illud facio non ego operor illud sed quod habitat in me peccatum ${ }^{21}$ invenio igitur legem volenti mihi facere bonum quoniam mihi malum adiacet ${ }^{22}$ condelector enim legi Dei secundum interiorem hominem ${ }^{23}$ video autem aliam legem in membris meis repugnantem legi mentis meae et captivantem me in lege peccati quae est in membris meis ${ }^{24}$ infelix ego homo quis me liberabit de corpore mortis huius ${ }^{25}$ gratia Dei per Iesum Christum Dominum nostrum igitur ego ipse mente servio legi Dei carne autem legi peccati: Biblia Sacra Iuxta Vulgatam. The Latin text of selected fragments of Thomas's commentary (English fragments of which are presented in the text) reads as follows: Deinde cum dicit ego autem carnalis sum, etc. ostendit conditionem hominis. Et potest hoc verbum dupliciter exponi. Uno quidem modo, ut apostolus loquatur in persona hominis in peccato existentis. Et ita hoc Augustinus exponit in libro LXXXIII quaestionum. Postea vero in libro contra Iulianum, exponit hoc ut apostolus intelligatur loqui in persona sua, id est, hominis sub gratia constituti. Prosequamur ergo declarando qualiter haec verba et sequentia diversimode possunt utroque modo exponi, quamvis secunda expositio melior sit. Quod ergo dicitur primo ego autem etc., sic intelligendum est, ut ly ego pro ratione hominis intelligatur, quae est principale in homine; unde videtur unusquisque homo esse sua ratio vel suus intellectus, sicut civitas videtur esse rector civitatis, ita ut quod ille facit, civitas facere videatur (Ad Rom 7:14, nos. 558-559). Infirmitas autem hominis est manifesta et ex hoc quod operatur id quod intelligit non esse operandum; unde dicitur quod enim operor, non intelligo, scilicet esse operandum. Quod quidem potest intelligi dupliciter. Uno modo de eo qui est subiectus peccato, qui quidem in universali intelligit non esse operandum peccatum, tamen victus suggestione Daemonis vel passione vel inclinatione perversi habitus, operatur illud. Et ideo dicitur operari quod intelligit non esse operandum contra conscientiam faciens; sicut, Lc. XII, v. 47 s.: servus sciens voluntatem domini sui et non faciens, digne plagis vapulabit multis. Alio modo potest intelligi de eo qui est in gratia constitutus. Qui quidem operatur malum, non quidem exequendo in opere vel consentiente mente, sed solum concupiscendo secundum passionem sensibilis appetitus, et illa concupiscentia est praeter rationem et intellectum, quia praevenit eius iudicium, quo adveniente talis operatio impeditur. Et ideo signanter non dicit intelligo non esse faciendum, sed non intelligo, quia scilicet intellectu nondum deliberato, aut praecipiente, talis operatio concupiscentiae insurgit. Gal. V, 17: caro concupiscit adversus spiritum, et spiritus adversus carnem (Ad Rom. 7:15, no. 563). The Latin text of this commentary is taken from http://www.corpusthomisticum.org/ cro05.html [accessed 4 April 2017]. 
exegetical explanation of the pronoun 'I' in Ad Rom. The second part includes the opinions of contemporary biblical scholars on the rhetorical 'I' of the pericope. The first scholar is Karl Barth whose well-known monograph Römerbrief is an example of the philosophical (or anti-philosophical) and theological approaches to St. Paul's epistle. The second scholar is Douglas J. Moo, who represents classical historical-critical exegesis of Romans.

\section{The rhetorical ' $I$ ' in Aquinas's reflections on Rom 7:14-25}

Aquinas presents two possible ways to read the 'I' in verse 7:14 of the Epistle to the Romans ("This passage can be interpreted in two ways: in one way so that the Apostle is speaking in the person of a man existing in sin; but later [...] he explained it as though the Apostle is speaking in his own person, i.e., of a man in the state of grace"5). He sees an exegetical problem with the pronoun 'I', one which had already appeared in ancient patristic exegesis. In Origen and most of the Greek Fathers, 'I' is understood to be a person existing in sin, whereas in Augustine and other Latin Fathers it is understood to be a person in the state of grace. ${ }^{6}$ In addition, Thomas specifically refers this personal pronoun to the person of St. Paul ("But later in a book against Julian he explained it as though the Apostle is speaking in his own person"7). No solution has been found to this dilemma in contemporary biblical studies, as we can see from the third point below. Aquinas prefers to read the rhetorical 'I' as a person in the state of grace, but in his commentary on Rom 7:14-25 he takes both possibilities into account ("Let us continue, therefore, by showing how these words and those that follow can be explained under both interpretations, although the second explanation is better"8). Thus, we are dealing with a double synoptic interpretation in his text.

5 Et potest hoc verbum dupliciter exponi; Uno quidem modo, ut apostolus loquatur in persona hominis in peccato existentis; Postea vero [...] exponit hoc ut apostolus intelligatur loqui in persona sua, id est, hominis. English translation of Ad. Rom: Thomas Aquinas, Lectures on the Letter to the Romans http://www.avemaria.edu/uploads/pagesfiles/4283.pdf [accessed 10 September 2013].

6 For the history of interpretation of this text see R.N. Longenecker, The Epistle to the Romans, pp. 652-656.

7 Postea vero in libro contra Iulianum, exponit hoc ut apostolus intelligatur loqui in persona sua.

8 Prosequamur ergo declarando qualiter haec verba et sequentia diversimode possunt utroque modo exponi, quamvis secunda expositio melior sit. 
Aquinas starts by explaining the meaning of the personal pronoun ego in verse 14. In his opinion, in this fragment we find the rhetorical figure of the synecdoche. ${ }^{9}$ The pronoun 'I' (ego) primarily means reason, as it is considered the most important part of a human being ("for man's reason, which is the chief thing in $\operatorname{man}^{\prime 10}$ ). Thus, Thomas states that man can be described using the term the reasoning mind ("hence each man seems to be his own reason or intellect"11). After a comment on the passage ego autem carnalis sum venundatus sub peccato, in which Aquinas explains the meaning of the term bodily reason, he goes on to discuss verse 15: quod enim operor non intellego (Ad Rom $7: 15$, no. 563).

In the first case we have a man who consciously commits sins. He knows that $\sin$ is forbidden but he sins anyway ("who understands in general that sin should not be committed"12). This is a result of his lifestyle. Aquinas uses here the Latin term victus. This sinful way of life can have three causes: influence of the devil (suggestione Daemonis), passions (passione), or acquired bad tendencies (inclinatione perversi habitus). Thomas emphasises that these deeds are contrary to conscience (conscientia). ${ }^{13}$ The following description of conscience appears in The Summa Theologiae:

Properly speaking, conscience is not a power, but an act. This is evident both from the very name and from those things which in the common way of speaking are attributed to conscience. For conscience, according to the very nature of the word, implies the relation of knowledge to something: for conscience may be resolved into 'cum alio scientia, i.e. knowledge applied to an individual case. But the application of knowledge to something is done by some act. Wherefore from this explanation of the name it is clear that conscience is an act (ST I Q. 79, Art. 13). ${ }^{14}$

9 More on this topic can be found in: H. Lausberg, Retoryka literacka, pp. 328-331.

10 Pro ratione hominis intelligatur, quae est principale in homine.

11 Homo esse sua ratio vel suus intellectus.

12 Qui quidem in universali intelligit non esse operandum peccatum.

13 For more on this concept: Conscientia, in: L. Schütz, Thomas-Lexikon. Sammlung, Übersetzung und Erklärung der in sämtlichen Werken des hl. Thomas von Aquin vorkommenden Kunstausdrücke und wissenschaftlichen Aussprüche, http://www.corpusthomisticum.org/tl.html [accessed 5 April 2017].

14 Respondeo dicendum quod conscientia, proprie loquendo, non est potentia, sed actus. Et hoc patet tum ex ratione nominis, tum etiam ex his quae secundum communem usum loquendi, conscientiae attribuuntur. Conscientia enim, secundum proprietatem vocabuli, importat ordinem scientiae ad aliquid, nam conscientia dicitur cum alio scientia. Applicatio autem scientiae ad aliquid fit per aliquem actum. English translation of ST: Thomas Aquinas, The Summa Theologica, http://dhspriory.org/thomas/english/summa/FP/FP079. html\#FPQ79A13THEP1 [accessed 10 April 2017]. 
Thus, Aquinas shows the tension between the cognitive order and the order of action. On the one hand, we have a cognitive verb, intelligo. On the other hand, we have derivates of the verb opero, e.g. in the syntagmas non esse operandum peccatum and non esse operandum. We also find the verb facio in the phrase contra conscientiam faciens. Both of these words are related to the sphere of sin and prohibited acts (peccatum and non esse operandum). In other words, the will expressed by deeds is subject to the reality of carnality (see a commentary on the phrase ego autem carnalis sum venundatus sub peccato). It seems that Thomas recognises a certain autonomy and freedom of corporeality in reference to the human reason. Earlier, Aquinas stated that reason might succumb to the flesh (Ad Rom 7:14, no. 560: "But man is called carnal, because his reason is carnal $[\ldots]$ in one way from the fact that it is submissive to the flesh and consents to things to which the flesh urges it [...] another way reason is said to be carnal, because it is under attack from the flesh"15), but here he emphasises that reason includes the general knowledge that one should avoid sin ("who understands in general that sin should not be committed"16). Do we perceive a contradiction here? This general reluctance to commit sin is most likely to refer to the first moral principle of natural law recognised by practical reason: bonum est faciedendum et prosequendum, et malum vitandum. ${ }^{17}$ Thus man does not want to commit evil deeds, but at the same time his mind may succumb to the flesh. In spite of everything, reason is characterised by a certain degree of autonomy and freedom, for example, in the case of knowing the basic norms of natural law. But at the same time we see the significant impact on human behaviour of what Aquinas described as a perverted way of life/lifestyle (victus). The relationship between ways of life, human activity, and the moral philosophy and mind of Thomas Aquinas in the light of Wittgenstein's philosophy is shown in the splendid monograph written by R. Pouivet. ${ }^{18}$

This part of the reflection ends with a quote from Luke 12:47: servus sciens voluntatem domini sui et non faciens, digne plagis vapulabit multis. We should remember that quotations from various books of the Bible in the works of Aquinas function not as ornaments but as demonstrations of a broader canonical perspective, in which a fragment of the pericope being commented on is included. This kind of canonical approach is still based on a historical/literal sense

15 Dicitur autem homo carnalis, quia eius ratio carnalis est [...] Uno modo ex eo quod subditur carni, consentiens his, ad quae caro instigat [...] Alio modo dicitur ratio esse carnalis, ex eo quod a carne impugnatur.

16 Qui quidem in universali intelligit non esse operandum peccatum.

17 W. Galewicz, Wstęp tłumacza, p. 17.

18 R. Pouivet, After Wittgenstein, St. Thomas. 
of Scripture (sensus literalis) and its divine authorship. ${ }^{19}$ Luke 12:47 is a fragment of Luke 12:35-48, containing various statements of Jesus on the need of vigilance. This collection shows a shift of stress from eschatological to moral vigilance, which is connected with Luke's attempt to solve the so-called eschatological crisis. ${ }^{20}$ Nevertheless, Aquinas's comment and the passage from the Gospel of Luke demonstrate the moral responsibility of man in fulfilling the will of God. In Aquinas's interpretation of Rom 7:15, God's will is contained in the conscience of the unredeemed man (see Aquinas's commentary on Rom 2:14-15).

In the other interpretation of Rom 7:15, Aquinas speaks about a man in the state of grace ("In another way it can be understood of one in the state of grace" ${ }^{21}$ ). Here, Aquinas, using the verb opero, insists that the redeemed man is basically evil (operatur malum). However, elsewhere in his work he clarifies that he has in mind the reality of desire (concupiscentia), ${ }^{22}$ which remains in the baptised/redeemed man as a trace of original sin ("but only by desiring through a passion in the sensitive appetite" 23 ). The desire (concupiscentia) to act arising in the sensitive appetite exists prior to the reason or intellect ("and that desire escapes the reason or intellect, because it exists before the intellect's judgment. When the judgment is made, the desire is impeded"24). Thus, on the one hand, we have a desire to act according to the body/flesh. Importantly, the concupiscentia is evil, but not in deed or in the consent of the mind ("He does evil not by performing the deed or consenting with the mind"25). On the other hand, we have our reason and free will under grace primarily associated with the soul. Thus, if we act in the power of the Holy Spirit, we can resist the desire.

The second interpretation is based on Thomas's anthropological principles, in which the rational dimension of the human being (our soul) dominates over the sensitive appetite (body/flesh). Nevertheless, at this point we should not

19 See more in: M. Healy, Aquinas's Use of the Old Testament, pp. 186-192.

20 On the so-called eschatological crisis and Luke's answer to this problem: J. Gnilka, Teologia Nowego Testamentu, pp. 271-276.

21 Alio modo potest intelligi de eo qui est in gratia constitutus.

22 Concupiscentia, in: Ludwig Schütz, Thomas-Lexikon. Sammlung, Übersetzung und Erklärung der in sämtlichen Werken des hl. Thomas von Aquin vorkommenden Kunstausdrücke und wissenschaftlichen Aussprüche, http://www.corpusthomisticum.org/ tl.html [accessed 5 April 2017].

23 Sed solum concupiscendo secundum passionem sensibilis appetitus.

24 Praeter rationem et intellectum, quia praevenit eius iudicium, quo adveniente talis operatio impeditur.

25 Non quidem exequendo in opere vel consentiente mente. 
forget that this anthropological dualism is based on the Aristotelian-Thomist conception of hylomorphism. In other words, man is a being composed of two elements: the soul (form) and the body (matter). The soul is not a human being but a substantial form. Thus, when we read about the struggle between the mind/soul and the concupiscentia linked to the body/flesh, we should remember that this occurs in one subject, one human being. This is a relatively positive and optimistic vision. However, we should also remember that prior to the resurrection, as long as we live in the fully-unredeemed world, even when living under grace, the concupiscentia still acts through our body/flesh. ${ }^{26}$

Aquinas refers to a person subject to sin and person in the state of grace in the singular, as for him this person is the Apostle Paul. However, the context might suggest that he was also thinking about every man. These two readings are not mutually exclusive. Paul represents the existential situation of every man. We can say that in Rom 7:14-25 the 'I' means the redeemed/unredeemed man in the singular reading, i.e. especially Paul, or redeemed/unredeemed men, in plural form, i.e. every believer or every sinner. Aquinas's interpretation of 'I' as a person under grace has great and truly deep existential potential and treats the common experience of every believer. When a reader becomes acquainted with Aquinas's commentary on Paul's letters for the first time, his scholastic language may seem dry and lifeless. But when we get involved in this scholastic language and understand the passion, spirituality, and the wisdom purpose of his theological activity, ${ }^{27}$ we can find deep insight into our existential situation, tension between our life in the state of grace - through sacraments and moral activity - and our life in the state of sin, because we still commit venial and sometimes mortal sins, as we still feel lust and desire in our existence according to the body/flesh. Aquinas, seeing this dialectical dimension of our life, discovers in Paul's thought a source which enables him to describe this ambiguity. In fact, Aquinas's interpretation seems truly existential and equivalent to the philosophy of Martin Heidegger, but we can see that this is only true when we participate in scholastic language games and scholastic metaphysical dialect.

26 On Paul's anthropology and its reinterpretation in Aquinas's philosophy and theology see B. Blankenhorn, Aquinas on Paul's Flesh/Spirit, pp. 1-51.

27 For more on the relationship between philosophy and theology as science and spiritual activity, see J.-P. Torrell, Święty Tomasz z Akwinu.; see also: M. Paluch (ed.), Święty Tomasz teolog. 


\section{Rom 7:14-25 and contemporary exegesis}

In this section two examples of contemporary commentaries on Rom 7:14-25 will be discussed. One, which is philosophical - though it might even be described as anti-philosophical - is Karl Barth's Epistle to the Romans (second edition, published 1922) ${ }^{28}$ The other is the historical-critical commentary on the Epistle to the Romans by Douglas J. Moo from the series The New International Commentary on the New Testament. ${ }^{29}$

Karl Barth's commentary on St. Paul's Epistle to the Romans (second edition, published 1922) is one of the most important philosophical and theological books of the twentieth century. Römerbrief is in opposition not only to Protestant liberal theology but also to metaphysical thought and natural theology. Barth's commentary on Rom 7:14-25 is entitled The Reality of Religion. ${ }^{30}$ For Barth, the Mosaic Law from Pauline theology is essentially identical to religion. In Barth's commentary on Rom 7:14-25 the Pauline ' $\mathrm{I}$ ' is not interpreted as either a person living in sin or one in the state of grace. Barth abandons this classic division, interpreting ' $I$ ' in the light of his philosophical (or, we may say, anti-philosophical) and anthropological assumptions. For Barth, every man lives in sin, because he lives in a world in which we can see only the traces of God and of His Revelation. This is because God is radically transcendent. In fact, there is no communication between us and God. This is what Barth called the diastasis. Only through faith and divine grace, which is a miracle, does man have a connection with God:

I am a man: and no emotion or enthusiasm of religion can obscure what this means. Only a new man, only a victor of my humanity, only eternal life, can release me from the enigma of my being. What, then, doth the Spirit profit me? What advantage does the law which proceeds from Spirit afford me? Of what use is my piety to me? How does the persuasive and prevailing power of God affect me? Is it not only too evident that I have no strength to bring forth? Depart from me; for I am a sinful man, O Lord (Luke 5:8). There is no bond of union between me, as I am, and God. ${ }^{31}$

K. Barth, The Epistle to the Romans.

D.J. Moo, The Epistle to the Romans.

K. Barth, The Epistle to the Romans, pp. 257-270.

Ibidem, p. 260. 
We see that Barth's commentary on Rom 7:14-25 is original, greatly marked by his anthropological and theological principia. Barth, like Aquinas, wants to be faithful to the Apostle Paul. However, in many places in Romans he reads this text against Paul's intentions. Another example is the pericope 1:18-32, in which Barth turns Paul's natural theology into a protest against anti-natural theology. For Barth, Paul's thought is only the starting point for his own reading. As in Aquinas's commentary, Barth uses the tools of philosophy, or of a kind of anti-philosophy, but the proportions and role of philosophy are radically different. For Aquinas, divine revelation, philosophy, divine truth, and the truth of reason are mutually complementary. Of course, divine truth is greater than reason, since through divine revelation we can discover truths such as the Holy Trinity, the Incarnation, and so on. For Barth we can come to know God only through revelation and faith. Philosophy shows only the limitations of human cognition.

The second example is The Epistle to the Romans, a commentary on Romans by Douglas J. Moo. Moo's work is a contemporary historical-critical commentary on the biblical book. In accordance with the historical-critical method, Moo's commentary focuses especially on the literal sense of Scripture. Thus, Moo analyses Rom 7:14-25, especially in the context of St. Paul's Epistle to the Romans and other works. Moo interprets the rhetorical 'I' as referring to a person in the state of $\sin$ (he uses the term unregenerate) or grace (he uses the term regenerate). Moo compares arguments for the first and second interpretations. ${ }^{32}$ The arguments for the unregenerate person are as follows: the pronoun ' $\mathrm{I}$ ' (Greek ego) is connected with 'the flesh' (Greek sarx) in 14:18-25; is in sin (v. 14b) and a prisoner of the law of sin (v. 23); The 'I' struggles with obedience to the Mosaic law. On the other hand, believers are released from the law and from the power of sin (vv. 6,2.6.11.14.18-22; 7,4-6). ${ }^{33}$ The arguments for the regenerate person are as follows: the ego in vv. 14-25 seeks to obey the law of God, but the unregenerate do not; the mind in vv. 14-25 is not opposed to God and observes the law of God; the concept of the 'inner man' refers to the Christian; Paul in vv. 14-25 uses present, in vv. 7-13 past tenses, thus underlining the shift from the experience of the unregenerate to that of the regenerate person. ${ }^{34}$ As we see, this commentary is limited to a literal interpretation, without the philosophical and systematic-theological inspiration we find in Barth's and Aquinas's texts. Moo takes into consideration the literary and theological

\footnotetext{
32 D.J. Moo, The Epistle to the Romans, pp. 445-448.

33 Ibidem, p. 445.

34 Ibidem, p. 446.
} 
context of the Epistle to the Romans and other writings of St. Paul. Finally, this researcher recognises that in Rom 7:14-25 we have the unregenerate man:

Our conclusion, already indicated in the exegesis of 7:7-12, is that vv. 14-25 describe the situation of an unregenerate person. Specifically, I think that Paul is looking back, from his Christian understanding, to the situation of himself, and other Jews like him, living under the law of Moses. Of course, Paul is not giving us a full picture of that situation; he is concentrating on the negatives because this is what he must do to prove how useless the law was in terms of delivering Jews from their bondage to sin. We might say, then, that Rom 7:14-25 describes from a personal viewpoint the stage in salvation history that Paul delineates objectively in Gal 3:19-4:3.35

\section{Conlusion}

This short review of Aquinas's commentary on Rom 7:14-25 and contemporary approaches to this text, focusing especially on the rhetorical 'I', shows that Paul's thought is still fascinating and has not been sufficiently examined. Different approaches, using many kinds of philosophical tools (for example scholastic, analytic, or existentially philosophical) as well as historical-critical and theological methods reveal the limitations of a single approach and afford a new look at the multiple senses of the Scripture, transcending the exclusively literal sense shown by the New Rhetoric and contemporary philosophy of language. This creates the possibility of multifaceted analysis of Scripture involving philosophers, theologians, and representatives of other disciplines, for example the social sciences. Thus we might say that Aquinas has contributed to renewal not only in biblical theology but also in biblical philosophy. This new approach to the relationship between Scripture, theology, and philosophy should abandon the mediaeval concept of philosophy as existing in the service of theology. Renewal of biblical philosophy should involve co-operation on the same level and afford deeper insight into the sense of Scripture. ${ }^{36}$

35 Ibidem, pp. 447-448.

36 Good examples of contemporary biblical philosophy include: J. Taubes, Teologia polityczna świętego Pawła; G. Agamben, Czas, który zostaje.; A. Badiou, Święty Pawet. 


\section{References}

Agamben G., Czas, który zostaje. Komentarz do Listu do Rzymian, trans. S. Królak, Warszawa 2009.

Badiou A., Święty Paweł: ustanowienie uniwersalizmu, trans. J. Kutyła, P. Mościcki, Cracow 2007.

Barth K., The Epistle to the Romans, trans. E.C. Hoskyns, London-Oxford-New York 1968.

Biblia Sacra Iuxta Vulgatam Versionem (Vulgate Latin Bible), Robert Weber et al. (eds.), Stuttgart 1983.

Blankenhorn B, Aquinas on Paul's Flesh/Spirit Anthropology in Romans, in: Reading Romans with St. Thomas Aquinas, M. Levering, M. Dauphinais (eds.), Washington 2012, pp. 1-51.

Concupiscentia, in: Thomas-Lexikon. Sammlung, Übersetzung und Erklärung der in sämtlichen Werken des hl. Thomas von Aquin vorkommenden Kunstausdrücke und wissenschaftlichen Aussprüche, Ludwig Schütz, http://www.corpusthomisticum.org/tl.html [accessed 5 April 2017].

Conscientia, in: Thomas-Lexikon. Sammlung, Übersetzung und Erklärung der in sämtlichen Werken des hl. Thomas von Aquin vorkommenden Kunstausdrücke und wissenschaftlichen Aussprüche, Ludwig Schütz, http://www.corpusthomisticum. org/tl.html [accessed 5 April 2017].

Dauphinais M., Levering M. (eds.), Reading John with St. Thomas Aquinas. Theological Exegesis and Speculative Theology, Washington 2005.

Galewicz W., Wstęp tłumacza, in: Traktat o prawie. Summa teologii I-II, q. 90-91, Tomasz z Akwinu, trans. W. Galewicz, Kęty 2014.

Gnilka J., Teologia Nowego Testamentu, trans. W. Szymona, Kraków 2002.

Healy M., Aquinas's Use of the Old Testament in His Commentary on Romans, in: Reading Romans with St. Thomas Aquinas, M. Levering, M. Dauphinais (eds.), Washington 2012, pp. 186-192.

Lausberg H., Retoryka literacka. Podstawy wiedzy o literaturze, trans. Albert Gorzkowski, Bydgoszcz 2002.

Levering M., Dauphinais M. (eds.), Reading Romans with St. Thomas Aquinas, Washington 2012.

Levering M., Pismo Święte i metafizyka. Tomasz z Akwinu i odnowa teologii trynitarnej, trans. M. Romanek, Kraków 2016.

Longenecker R.N., The Epistle to the Romans. A Commentary on the Greek Text, Grand Rapids 2016.

Moo D.J., The Epistle to the Romans, Grand Rapids-Cambridge 1996.

Paluch M. (ed.), Święty Tomasz teolog. Wybór studiów, Warszawa-Kęty 2005.

Pouivet R., After Wittgenstein, St. Thomas, trans. Michael S. Shervim, South Bend 2006.

Prügl T., Thomas Aquinas as Interpreter of Scripture, in: The Theology of Thomas Aquinas, R. Nieuwenhove, J. Wawrykow (eds.), Notre Dame 2005), pp. 386-415. 
Roszak P., Vijgen J. (eds.), Reading Sacred Scripture with Thomas Aquinas. Hermeneutical Tools, Theological Questions and New Perspectives, Turnohout 2015.

Roszak P., Vijgen J. (eds.), Towards a Biblical Thomism. Thomas Aquinas and the Renewal of Biblical Theology, Pamplona 2018.

Taubes J., Teologia polityczna świętego Pawła, trans. M. Kurkowa, Warsaw 2010.

Thomas Aquinas, Lectures on the Letter to the Romans, trans. Fabian Larcher, http:// www.avemaria.edu/uploads/pagesfiles/4283.pdf [accessed 10 September 2013].

Thomas Aquinas, The Summa Theologica, trans. Fathers of the English Dominican Province, http://dhspriory.org/thomas/english/summa/FP/FP079.html\#FPQ79A13THEP1 [accessed 10 April 2017].

Tomasz z Akwinu, Wykład listu do Kolosan. Super Epistolam B. Pauli ad Colossenese Lectura, P. Roszak (ed.), trans. I. Mikołajczyk, P. Roszak, Torun 2012.

Tomasz z Akwinu, Wykład pierwszego listu do Tymoteusza. Super Primam Epistolam B. Pauli ad Timotheum Lectura, Piotr Roszak, Enrique Alarcón (eds.), trans. Marian Hanusek, Toruń 2016.

Torrell J-P., Święty Tomasz z Akwinu. Mistrz duchowy, trans. Agnieszka Kuryś, PoznańWarszawa 2003.

Torrell J.-P., Tomasz z Akwinu - człowiek i dzieło, trans. Agnieszka Kuryś, WarszawaKęty 2008.

Wielockx R., Au sujet du commentaire de Saint Thomas sur le "Corpus Paulinum". Critique littéraire, in : Doctor Communis. L'interpretazione di San Tommaso delle dottrine di San Paolo, Vatican City 2009, pp. 150-177. 